\title{
HUBUNGAN ANTARA DIABETES MELITUS TIPE II DENGAN KEJADIAN GAGAL GINJAL KRONIK DI RUMAH SAKIT PKU MUHAMMADIYAH YOGYAKARTA PERIODE JANUARI 2011-OKTOBER 2012
}

\author{
Sari N, ${ }^{1}$ Hisyam B. ${ }^{2}$ \\ ${ }^{1}$ Mahasiswa Fakultas Kedokteran Universitas Islam Indonesia \\ ${ }^{2}$ Departemen Ilmu Penyakit dalam Fakultas Kedokteran Universitas Islam Indonesia
}

\begin{abstract}
ABSTRAK
Latar Belakang

Diabetes melitus (DM) merupakan kelompok penyakit metabolik yang berkaitan dengan meningkatnya glukosa darah dan diperkirakan akan meningkat secara drastis dan terjadi ledakan yang luar biasa dalam 1 atau 2 dekade mendatang. Diabetes melitus yang paling sering terjadi saat ini adalah diabetes melitus tipe II. Hiperglikemik kronis pada diabetes melitus berkontribusi terhadap munculnya berbagai komplikasi berupa kerusakan, disfungsi dan kegagalan berbagai organ seperti mata, ginjal, saraf, jantung dan pembuluh darah. Penderita DM cenderung berisiko 17 kali lipat terjadi gagal ginjal kronik.
\end{abstract}

\section{Tujuan}

Untuk mengetahui hubungan antara diabetes melitus tipe II dengan kejadian gagal ginjal kronik di Rumah Sakit PKU Muhammadiyah Yogyakarta Periode 1 Januari 2011 Oktober 2012.

\section{Metode}

Penelitian ini merupakan penelitian deskriptif analitik dengan metode cross sectional. Data diambil dengan metode consecutive sampling dari data sekunder berupa catatan rekam medis pasien dengan diabetes melitus tipe II di Rumah Sakit PKU Muhammadiyah Yogyakarta periode Januari 2011 - Oktober 2012. Analisis data dilakukan dengan uji ChiSquare.

\section{Hasil}

Terdapat hubungan bermakna antara diabetes melitus tipe II dengan gagal ginjal kronik dengan nilai $p=0,000(p<0,05)$ dan Confidence interval (CI) 2,3-7,8.

\section{Kesimpulan}

Terdapat hubungan bermakna antara diabetes melitus tipe II dengan kejadian gagal ginjal kronik di Rumah Sakit PKU Muhammadiyah Yogyakarta periode 1 Januari 2011 Oktober 2012.

Kata Kunci : Diabetes Melitus tipe II, gagal ginjal kronik, cross sectional, Rumah Sakit PKU Muhammadiyah Yogyakarta. 


\section{ABSTRACT}

\section{Background}

Diabetes mellitus (DM) is a group metabolic diseases characterized by elevated blood glucose levels. Diabetes is predicted to increase dramatically in the next 10-20 years. Type 2 diabetes is the most common form of diabetes. Chronic hyperglycaemia is associated with long-term damage disfunction and failure of normal functioning of various organs, especially the eyes, kidneys, nerves, heart and blood vessels. Patient with DM have 17 times higher risk for the kidney failure.

\section{Objective}

To find out the correlation between type II diabetes mellitus and incident renal failure in PKU Muhammadiyah Yogyakarta Hospital at the period of 1 January 2011 -October 2012.

\section{Methods}

This was a cross-sectional descriptive study. One hundred and ninety-two patients were included in this study. Consecutive sampling technique was used for data collection. Patient's record were reviewed to obtain data pertaining to age sex, glucose blood test and present of chronic renal failure. Diabetic patients suffering from any other medical problems such as hypertension, tuberculosis and urolithiasis were excluded from this study. The data analysis was done by ChiSquare test.

\section{Results}

Incident chronic renal failure had a significant correlation with type 2 diabetes mellitus ( $p<0.05$; $95 \%$ confidence interval 2.3 to 7.8 ).

\section{Conclusion}

There was a significant correlation between type II diabetes mellitus with incident chronic renal failure at PKU Muhammadiyah Yogyakarta Hospital, in the period of 1 January 2011 -October 2012.

Keywords : type II diabetes mellitus, chronic kidney failure, cross sectional, PKU Muhammadiyah Yogyakarta Hospital.

\section{PENDAHULUAN}

Di antara penyakit degeneratif, Diabetes Melitus (DM) merupakan salah satu ancaman kesehatan manusia. Penyakit ini tidak menular, tetapi jumlah penderitanya akan terus meningkat di masa mendatang. Menurut American Diabetes Association (ADA) tahun 2010, DM merupakan suatu kelompok penyakit metabolik dengan karakteristik hiperglikemia yang terjadi karena kelainan sekresi insulin, kerja insulin, atau keduaduanya. ${ }^{1}$

$$
\text { Berdasarkan penyebabnya DM }
$$
dibedakan menjadi DM tipe I dan DM tipe II. Berbagai penelitian epidemiologi menunjukkan adanya kecenderungan peningkatan angka insidensi dan prevalensi DM tipe II di berbagai penjuru dunia dan peningkatan prevalensi DM ini sangat mengkhawatirkan dengan total 3 juta kasus kematian akibat DM. ${ }^{2}$ 
Di seluruh dunia, jumlah penderita diabetes diproyeksikan akan mengalami peningkatan dari 171 juta pada tahun 2000 menjadi 366 juta pada tahun $2030 .^{3}$ Lonjakan yang drastis ini akan terjadi di negara berkembang, di mana diperkirakan bahwa jumlah orang dewasa yang terkena DM akan naik 246\% dari 115 juta menjadi 284 juta. $^{4}$

Diabetes melitus sudah mencapai proporsi terbanyak di negara berkembang, termasuk di Indonesia. Pada tahun 2000, dilaporkan bahwa 8,5 juta orang di Indonesia menderita diabetes dan jumlah ini diperkirakan mencapai 22 juta pada tahun 2030. ${ }^{3}$ Indonesia memiliki tingkat prevalensi diabetes tertinggi ke empat setelah India, Cina, dan Amerika Serikat. ${ }^{4}$ Berdasarkan pola pertambahan penduduk, diperkirakan pada tahun 2030 nanti akan ada 194 juta penduduk yang berusia di atas 20 tahun dan dengan asumsi prevalensi di daerah urban sebesar $14,7 \%$ dan rural 7,2\% maka diperkirakan 12 juta penyandang diabetes di daerah urban dan 8,1 juta di daerah rural. ${ }^{1}$

Hiperglikemik kronik pada DM berkontribusi terhadap munculnya berbagai komplikasi, kerusakan jangka panjang, disfungsi dan kegagalan berbagai organ seperti mata, ginjal, saraf, jantung dan pembuluh darah. ${ }^{5}$ Penderita diabetes dibandingkan dengan non-diabetes memiliki kecenderungan 2 kali lebih mudah mengalami trombosis serebral, 25 kali menjadi buta, 2 kali terjadi penyakit jantung koroner, 17 kali terjadi gagal ginjal kronik, dan 50 kali terjadi ulkus diabetika. ${ }^{6}$

Gagal ginjal akibat DM disebut juga nefropati diabetika. Berbagai teori seperti peningkatan produk glikosilasi nonenzimatik, peningkatan jalur poliol, glukotoksisitas, dan protein kinase-C memberikan kontribusi pada kerusakan ginjal. Terjadi perubahan pada membran basalis glomerulus yaitu proliferasi dari selsel mesangium. Hal ini menyebabkan glomerulosklerosis dan berkurangnya aliran darah sehingga terjadi perubahan permeabilitas membran basalis glomerulus yang ditandai dengan timbulnya albuminuria. Selain itu, akhir-akhir ini penelitian klinis mendapatkan adanya sklerosis dan gagal ginjal, yang mana dapat berkontribusi terhadap kematian. ${ }^{7}$

Tingkat insidensi gagal ginjal kronik di Indonesia akhir-akhir ini cenderung meningkat. Masih diperkirakan angka terjadinya gagal ginjal terminal di Indonesia sebesar 200-250 orang/1juta penduduk/ tahun. $^{8}$ Terjadinya gagal ginjal terminal dapat mempengaruhi kualitas hidup, 
sehingga insidensi kematian karena gagal ginjal terminal (end stage renal disease) ini juga semakin meningkat sesuai dengan peningkatan kejadiannya. Kematian yang terjadi di Amerika Serikat dilaporkan mencapai 71.000 pada tahun 2000 dan diperkirakan akan meningkat mencapai 352.000 pada tahun $2030 .{ }^{9}$

Mengingat besarnya kontribusi diabetes menyebabkan gagal ginjal kronik, hingga menyebabkan kematian di negara maju, termasuk Indonesia diperlukan suatu data untuk mengetahui kejadian gagal ginjal kronik, khususnya untuk pasien yang telah memiliki faktor risiko tinggi salah satunya adalah DM. Untuk mendapatkan data tersebut perlu dilakukan sebuah penelitian untuk mengetahui hubungan DM tipe II dengan kejadian gagal ginjal kronik yang dalam penelitian ini dilakukan di Rumah Sakit PKU Muhammadiyah Yogyakarta periode 1 Januari 2011 - Oktober 2012.

\section{METODE PENELITIAN}

Penelitian ini menggunakan desain cross-sectional dimana data hanya diambil satu kali dalam kurun waktu tertentu. Data yang dipakai merupakan data sekunder berupa catatan kasus rekam medis pasien dengan DM tipe II positif dam negatif di Rumah Sakit PKU Muhammadiyah
Yogyakarta periode 1 Januari 2011 Oktober 2012.

Populasi target dalam penelitian ini adalah pasien dengan penyakit DM tipe II yang berusia lebih dari sama dengan 20 tahun. Sedangkan populasi terjangkau adalah pasien dengan penyakit DM tipe II yang berusia lebih dari sama dengan 20 tahun yang berobat dan terdaftar dalam rekam medis di Rumah Sakit PKU Muhammadiyah Yogyakarta periode 1 Januari 2011 - Oktober 2012. Sampel yang digunakan merupakan bagian dari populasi terjangkau yang memenuhi kriteria inklusi dan eksklusi. Kriteria inklusi adalah semua pasien DM tipe II yang telah diperiksa kadar glukosa darah puasa dan atau sewaktu, disertai dengan penyakit gagal ginjal kronik maupun tidak disertai gagal ginjal kronik dan pasien gagal ginjal kronik yang telah didiagnosis dokter dan melakukan tes fungsi ginjal. Sedangkan kriteria eksklusi adalah Penyakit lain yang mendasari gagal ginjal kronik seperti Tuberkulosis (TBC), hipertensi, urolithiasis.

Sampel dipilih dengan menggunakan consecutive sampling yaitu pasien yang memenuhi kriteria penelitian akan digunakan sebagai sampel. Berdasarkan rumus besar sampel dari Sastroasmoro et al. 
(2008), besar sampel yang diperlukan dalam penelitian ini sebanyak 192 sampel. ${ }^{10}$

Pasien dengan DM tipe II merupakan pasien yang memiliki kadar gula darah sewaktu $(\mathrm{GDS}) \geq 200 \mathrm{mg} / \mathrm{dL}$ dan atau kadar gula darah puasa (GDP) $\geq 126 \mathrm{mg} / \mathrm{dL}$. Sedangkan non-DM tipe II adalah kadar GDS <200 mg/dL dan atau GDP <126 mg/dL. Dikatakan gagal ginjal kronik jika terdapat kelainan struktur atau fungsi ginjal, dengan atau tanpa penurunan laju filtrasi glomerulus (LFG) sebesar $\quad<60$ $\mathrm{ml} / \mathrm{menit} / 1,73 \mathrm{~m}^{2}$. Data yang diambil sesuai Standar Pelayanan Minimal RS PKU Muhammadiyah Yogyakarta (2010), yaitu berdasarkan diagnosis klinis dan hasil laboratorium kadar kreatinin, kemudian diukur LFG dengan rumus Cocroft-Gault :
Variabel pada penelitian ini adalah sebagai berikut :

a. Variabel bebas : kadar glukosa darah sewaktu dan atau glukosa darah puasa pasien DM tipe II.

b. Variabel tergantung : kadar ureum dan kreatinin pasien gagal ginjal kronik.

Instrumen dalam penelitian ini menggunakan data sekunder berupa data rekam medis pasien yang diperoleh data mengenai hasil pemeriksaan laboratorium baik kadar gula darah sewaktu dan atau puasa, kadar ureum, kreatinin, serta penyakit lain dalam kriteria pemilihan sampel. Berdasarkan rancangan penelitian, data dianalisis menggunakan dengan uji Chi-Square.

Tabel 1. Distribusi Karakteristik Sampel Penelitian

\begin{tabular}{llcc}
\hline No & Karakteristik Sampel & N & \% \\
\hline 1 & Jenis Kelamin & & \\
& a. Laki-laki & 95 & 49.5 \\
& b. Perempuan & 97 & 50.5 \\
& Total & 192 & 100 \\
2 & DM Tipe II & & \\
& a. Ya & 96 & 50 \\
& b. Tidak & 96 & 50 \\
& Total & 192 & 100 \\
3 & GGK & & \\
& a. Ya & 77 & 40.1 \\
& b. Tidak & 115 & 59.9 \\
& Total & 192 & 100 \\
\hline
\end{tabular}

LFG $=(140$-usia $) \times$ berat badan $/(72 \times$ kadar kreatinin plasma $)$

HASIL DAN PEMBAHASAN 
Jumlah sampel pada penelitian ini negatif pada sampel penelitian ini seimbang sebanyak 192 orang, dimana 96 orang yaitu 50\% pada DM tipe II positif dan 50\% termasuk pasien DM tipe II positif dan 96 pada DM tipe II negatif. Pada distribusi

Tabel 2. Hasil Analisis Data dengan Uji Chi-Square

\begin{tabular}{|c|c|c|c|c|c|c|c|}
\hline & & \multicolumn{4}{|c|}{ GGK } & \multirow{3}{*}{ Total } & \multirow{3}{*}{$p$} \\
\hline & & \multicolumn{2}{|c|}{ Ya } & \multicolumn{2}{|c|}{ Tidak } & & \\
\hline & & $\overline{\mathbf{N}}$ & $\%$ & $\overline{\mathbf{N}}$ & $\%$ & & \\
\hline \multirow{3}{*}{$\mathrm{DM}$} & Ya & 60 & 62.5 & 36 & 37,5 & 96 & \multirow{3}{*}{0,000} \\
\hline & Tidak & 27 & 28.1 & 69 & 71,9 & 96 & \\
\hline & Total & 87 & 45.3 & 105 & 54,7 & 192 & \\
\hline
\end{tabular}

orang termasuk DM tipe II negatif. Sampel dalam penelitian ini merupakan pasien yang tercatat di Rumah Sakit PKU kronik.

Muhammadiyah Yogyakarta Periode 1 Januari 2011 sampai Oktober 2012 yang memenuhi kriteria inklusi seperti yang sudah disebutkan sebelumnya dan sampel yang diambil menggunakan metode consecutive sampling. Distribusi karakteristik sampel penelitian tersaji dalam Tabel 1.

Dari Tabel 1 dapat dilihat bahwa pada penelitian ini distribusi jenis kelamin pada sampel lebih banyak pada perempuan yaitu 50,5\%. Distribusi DM tipe II positif dan gagal ginjal kronik, sebanyak 59,9\% sampel penelitian tidak memiliki gagal ginjal kronik.

Hasil analisis data menggunakan Chi-Square tersaji pada Tabel 2 dan diperoleh nilai $p=0,000(p<0,05)$ dan Confidence interval (CI) 95\%; 2,3-7,8. Secara statistik hal ini menunjukkan bahwa hipotesis nol (H0) ditolak karena terdapat hubungan antara DM tipe II dengan kejadian gagal ginjal kronik.

Pada Tabel 3 tersaji data Rasio Prevalens sebesar 2,22 dengan Confidence Interval (CI) sebesar 95\%, 2,3-7,8 dan rasio prevalensi $>1$ dimana artinya terdapat

Tabel 3. Perhitungan rasio prevalens

\begin{tabular}{|c|c|c|c|c|}
\hline \multirow{2}{*}{$\mathrm{RP}=$} & $\mathrm{a}$ & & c & \multirow{2}{*}{$\begin{array}{l}\text { Keterangan } \\
a=60\end{array}$} \\
\hline & $a+b$ & & $\overline{c+d}$ & \\
\hline & 60 & & 27 & $b=36$ \\
\hline $\mathrm{RP}=$ & 96 & + & 96 & $c=27$ \\
\hline $\mathrm{RP}=$ & 2,22 & & & $\mathrm{~d}=69$ \\
\hline
\end{tabular}


hubungan antara DM tipe II dengan kejadian gagal ginjal kronik.

Penelitian sebelumnya yang menggunakan desain Cross-sectional dengan jumlah sampel 100 orang memperoleh hasil bahwa terdapat hubungan signifikan antara mikroalbuminuria dengan DM tipe II. ${ }^{11}$

Hasil penelitian tersebut berbeda dengan hasil penelitian lain yang bersifat observasional menggunakan studi crosssectional dengan jumlah sampel 40 orang yang memperoleh hasil bahwa kadar gula darah bukan merupakan faktor risiko atau tidak berhubungan terhadap kejadian gagal ginjal kronik pada DM tipe II di Rumah Sakit PKU Muhammadiyah Yogyakarta. ${ }^{12}$

\section{KESIMPULAN}

Pada penelitian ini dapat disimpulkan bahwa terdapat hubungan signifikan antara DM tipe II dengan kejadian gagal ginjal kronik $p=0,000(\mathrm{p}<$ 0,05, CI 2,3-7,8) di Rumah Sakit PKU Muhammadiyah Yogyakarta periode Januari 2011 - Oktober 2012.

\section{SARAN}

Diharapkan kepada peneliti berikutnya agar lebih memperluas cakupan penelitiannya sehingga dapat lebih bermanfaat dalam perkembangan ilmu pengetahuan di bidang kedokteran dan kesehatan dan perlu diadakan penelitian lanjutan dengan variabel glikosilasi hemoglobin (HbA1c) sebagai dasar dalam menentukan terkontrol tidaknya kadar gula darah pada penderita DM.

\section{DAFTAR PUSTAKA}

1. PERKENI. Konsensus Pengendalian dan Pencegahan Diabetes Mellitus Tipe 2 Di Indonesia. Jakarta: PB PERKENI, 2011.

2. Roglic G, Unwin N, Benneth PH. The Burden of Mortality Attributable to Diabetes : Realistic Estimates for The Year 2000. Diabetes Care 2005;28:2130-5.

3. Padmawati, RS, Nawi NG, Prabandari YS, Nicther M. Smoking Among Diabetese Patients in Yogyakarta, Indonesia : Cessation Effort are Urgently Needed. Tropical Medicine and International Health 2009;14(4):412-9.

4. Wild S, Roglic G, Green A, Sicree R, King H. Global Prevalence of Diabetes : Estimates for The Year 2000 and Projection for 2030. Diabetes Care 2004;27:1047-53.

5. Dabla P.K. Renal Function in Diabetic Nephropathy. World J Diabetes 2010;1(2):48-56.

6. Tjokroprawiro A. Hidup Sehat dan Bahagia bersama Diabetes Melitus. Jakarta: Gramedia Pustaka Utama, 2006.

7. Soni A. Diabetes Melitus sebagai Faktor Risiko Kejadian Gagal Ginjal Terminal (Studi Kasus Pada Pasien RSUD Prof. Margono Soekarjo Purwokerto). Jurnal epidemiologi 2005.

8. Bakri S. Deteksi Dini Dan Upaya-Upaya Pencegahan Progresifitas Penyakit Gagal Ginjal Kronik. Jurnal Medika Nusantara 2005;26(3):36-9.

9. Schoolwerth AC, Engelgau M, M., Hostetter TH, Rufo K.H, McClelan WM. Chronic Kidney Disease a Public Health 
Problem That Needs a Public Health Action Plan. Prevention Chronic Disease 2006;3(2):1-5.

10. Sastroasmoro, Sudigdo, Ismael S. DasarDasar Metodologi Penelitian Klinis. Jakarta : Sagung Seto, 2008.

11. Sheikh SA, Baig JA, Iqbal T, Kazmi T, Baig M, Husain SS.
12. Prevalence of Microalbuminuria with Relation to Glycemic Control In Type-2 Diabetic Patients In Karachi. Ayub Med Coll Abbottabad 2009;21(3): 83-6.

13. Musa RR. Kadar gula darah sebagai faktor risiko gagal ginjal kronik pada diabetes melitus tipe II di RS PKU Muhammadiyah Yogyakarta. UNISBA, 2010. 